\title{
TEACHERS AS RESEARCHERS? ASSESSING IMPACT OF PEDAGOGICAL INTERVENTIONS ON PUPILS' ATTITUDES ${ }^{1}$
}

\author{
PETER DRÁL AND ANDREJ FINDOR
}

\begin{abstract}
The paper suggests that there is a gap between the research on prejudice in Slovak schools and the pedagogical interventions used to reduce them, particularly in relation to the Roma minority. It highlights the existing curricular requirements for dealing with intergroup relations, stereotypes and prejudice, contrasting them with the organizational, methodological and practical constraints teachers face when trying to meet them. Drawing from experience of piloting alternative tools for measuring attitudes, designing interventions and assessing impact, the article describes one possible way of bridging the gap.
\end{abstract}

Key words: stereotype; prejudice; prejudice reduction; pedagogical intervention; curriculum.

\section{Introduction}

This paper is part of the monothematic symposium Measuring anti-Roma Prejudice in Slovakia published in this issue. The papers were conceived of during the initial phase of INTERMIN $^{2}$, a project that brings together researchers from various disciplines, and with different methodological backgrounds and practical experience ${ }^{3}$, who design instruments to

${ }^{1}$ This work was supported by the Slovak Research and Development Agency, under contract no. APVV-14-0531.

${ }^{2}$ INTERMIN is the abbreviated title of the following project - Interventions for Reducing Prejudice against Stigmatized Minorities: Developing measures and experimental testing of the contact hypothesis under field conditions. The main objective is to perform randomized controlled trials to assess the effectiveness of intergroup contact interventions in reducing prejudice against stigmatized minorities, especially the Roma minority. Specifically, we plan to compare the effects of direct, vicarious and imagined contact interventions among secondary school students, using explicit and implicit measures. In the first phase the main task is to design measures to assess attitudinal and behavioural change produced by different types of contact situations that would work in Slovakia where there are major status differences and strong intergroup boundaries between the Roma minority and the non-Roma majority. For more details on the project, see Lášticová \& Findor (2016, this issue).

${ }^{3}$ The members of the research team are: Barbara Lášticová (principal investigator), Magda Petrjánošová, Simona Andraščiková (all from the Institute for Research in Social Communication,

(C) Institute for Research in Social Communication, Slovak Academy of Sciences 
measure prejudice and develop prejudice reduction interventions. In this article we argue that the two 'worlds' of academic research and teaching practice are divided by a gap which means that research findings are detached from classroom interventions and pedagogical attempts remain largely uninformed by existing research.

We first present major findings from the existing research on the attitudes, stereotypes and prejudice broadly consistent across Slovak society concerning the Roma minority. We briefly highlight similarities in the extent and strength of anti-Roma prejudice in central Europe generally. Secondly, we examine more closely the research on attitudes among teachers and pupils, the groups targeted by the INTERMIN project, in order to identify any specific features of these groups that could affect the design of the interventions. Thirdly, we analyse the existing systemic, especially curricular, methodological and organizational conditions for prejudice reduction in the Slovak education system so as to better understand the actual opportunities teachers have to shape the intergroup attitudes of their pupils. Fourthly, we present an alternative, non-academic measure of attitudes piloted as part of a long-term course for teachers on multicultural and global education. Despite its limited focus and the lack of rigorous methodology we see the developed support for teachers as a viable strategy for bridging the gap between the academic world and teaching practice which could be both methodologically sound and of practical use in the classroom. In conclusion we draw on some of the lessons learned from applying this approach for other researchers who are willing to help educational practitioners.

In this paper we do not present the theoretical underpinnings and methodological challenges of the INTERMIN project. We refer readers to the other papers in this symposium for details on the conceptualization of prejudice within the contact paradigm, an overview of the existing explicit measures typically used to measure prejudice in social psychology and for the challenges faced in adapting them for use in Slovakia (Lášticová \& Findor, 2016; Popper \& Petrjánošová, 2016, this issue) ${ }^{4}$

\footnotetext{
Slovak Academy of Sciences), Andrej Findor, Martin Kanovský, Miroslav Popper, Peter Drál' (all from the Faculty of Social and Economic Sciences, Comenius University in Bratislava), and Miroslav Sirota from the University of Essex, UK.

${ }^{4}$ Lášticová and Findor (2016, this issue) ground the INTERMIN methodology in Allport's (1979) contact paradigm. They argue that while the positive effects of direct contact are widely documented, various forms of indirect contact have also proved to have prejudice reducing effects and look at the extended contact hypothesis, vicarious contact and imagined intergroup contact. They justify adopting measures for use in Slovakia that deliberately do not focus on intra-individual explanations of prejudice on their critical assessment of the current social psychology research on prejudice.

Popper \& Petrjánošová (2016, this issue) analyse the main challenges faced in adapting standardised measures. They cluster them around six issues: 1) who exactly do the participants have in mind when completing the questionnaires; 2) whose viewpoint are they conveying in their answers; 3 ) the period of time and location referred to in the questions; 4) translating and the transferability of meaning between languages; 5) assumptions that distinctive items are logically interconnected; and 6) double negation. The authors argue that if researchers use questionnaires without having subjected them to prior scrutiny through cognitive interviews, they are not entirely in control of what they are "really asking", i.e. what the participants understand when reading and answering the questions.
} 


\section{The broader context of prejudice reduction in Slovakia}

Slovakia is an ethnically diverse country with thirteen officially recognised national minorities (Report on the situation and rights of persons belonging to national minorities 2014, 2015, p. 20). ${ }^{5}$ In the last census conducted in 2011 more than $12 \%$ of a population of 5.4 million declared their ethnicity to be other than Slovak (Juhaščíková, Škápik \& Štukovská, 2012, p. 10). The population of Roma is thought to be higher than that recorded by the census and is estimated to bring the total minority population to over $17 \%{ }^{6}$ Approximately $40 \%$ of the Roma population lives in segregated settlements or on the periphery of towns and villages (Atlas, 2014, p. 16).

As in other central European countries, a large amount of evidence indicates that there are structural inequalities and the Roma in Slovakia suffer from socioeconomic marginalisation, which is manifest in a number of areas including education (Drál, Kostlán, \& Kusá, 2008; Huttová, McDonald, \& Harper, 2008; Kusá, Kostlán, \& Rusnáková, 2010b; Szalai, 2011), and this has clear implications for the future of interethnic relations (Kusá, Drál, \& Kostlán, 2008; Law, Nekorjak, Daniel, \& Vajda, 2009). The great social distance between the majority population and the Roma prevails across different segments of Slovak society regardless of age, gender, education or socio-economic status (Vašečka, 2001), and the strength of negative attitudes has not altered in recent decades (Vašečka, 2002; Kotvanová, Müncnerová, \& Chaloupka, 2008).

Eurobarometer surveys show that there is significantly greater social distance between the majority population and the Roma in Slovakia in comparison to other EU countries (European Commission, 2008). Although the longitudinal European Values Study indicated a general increase in tolerance of almost all outgroups, including a surprisingly sharp decrease in the social distance between the majority and Roma populations (from $71 \%$ in 1991 and $77 \%$ in 1999 to $47 \%$ in 2008), this decrease has not been recorded since and has been attributed to the wider adoption of politically correct views (Kusá \& Zeman, 2009). The most recent Eurobarometer survey shows more than one third of the Slovak population (36\%) would be 'totally uncomfortable' having a Roma colleague, and only $17 \%$ of respondents (EU average is 53\%) declared they would feel comfortable if their child was in a romantic relationship with a Roma (European Commission, 2015).

\section{Research on prejudice in Slovak schools}

Broadly shared negative attitudes towards Roma translate into an alarming prevalence and intensity of prejudice among young people (Hradiská \& Ritomský, 2007; Gallová Kriglerová

\footnotetext{
${ }^{5}$ These are the Hungarian, Roma, Ruthenian, Ukrainian, Czech, German, Polish, Croatian, Serbian, Russian, Jewish, Moravian and Bulgarian minorities.

${ }^{6}$ In the last census those who regarded themselves as Roma represented less than $2 \%$ of the population, and many individuals of Roma origin reportedly declared their ethnicity to be Slovak or Hungarian. The Atlas of Roma Communities commissioned by the Slovak government for policy purposes collected data based on external ascription. According to the data, more than 400 thousand citizens $(7.4 \%$ of the total population) are thought to be Roma, and they predominantly inhabit the eastern parts of Slovakia (Atlas, 2014, p. 16).
} 
\& Kadlečíková, 2009; Kusá, Kostlán, \& Rusnáková, 2010b; Farkašovská, 2011; Slovíková, 2012; Bieliková et al., 2013). Although the research varied in purpose and methodology, the findings unanimously point to the widespread persistence of prejudice among the schoolaged population against Roma, Hungarians and LGBTIQ persons.

A representative survey conducted as part of the All Different-All Equal campaign targeting 14 to 26 year olds revealed that although young people express generally positive attitudes to cultural diversity, their perceptions of and relations with specific groups differ significantly and indicate that the intensity of intergroup contact may have a moderating effect (Gallová Kriglerová, 2006). ${ }^{7}$

Another survey on a representative sample of 13 to 15 years old pupils found that two thirds of the respondents positively embraced cultural diversity and that exposure to "difference" within the family plays a role (Gallová Kriglerová \& Kadlečíková, 2009). However, positive perceptions of groups again differed, and frequency of contact did not mitigate negative perceptions of the Roma. The research also revealed that knowledge of different cultures is very low among young people, although the ratio of pupils' correct answers rises in line with the educational attainment of their parents. However, better knowledge does not affect the valence and intensity of attitudes. ${ }^{8}$

A similar finding was recorded in research among 16 to 17 years old who expressed tolerant views of otherness despite $60 \%$ of them admitting they did not have enough information about the ethnic groups in Slovakia. Stereotypical and less accepting views were again noted in regard to the Roma, especially among boys. Interestingly, the larger the town or village inhabited by the respondents, the fewer Roma friends they had (Hradiská \& Ritomský, 2007). Another research among primary and secondary pupils showed that most of them would object to having to sit next to a Roma classmate. The proportion was several times higher than that found in all other groups (Slovíková, 2012). ${ }^{9}$

Most recently, the State School Inspectorate's assessment of human rights education in primary and secondary schools indicated that pupils' performances in human rights topics were deteriorating and admitted that teaching in schools may only have a limited impact

\footnotetext{
${ }^{7}$ Most respondents $(70 \%)$ considered relations between the majority population and the Roma minority to be "fairly bad" or "very bad". Knowing a Roma did not affect the overall assessment of intergroup relations, although those who regularly encountered Roma in their environment were slightly more positive. Young people falling into this category were more likely to say that people in Slovakia were disadvantaged because of their ethnicity. In addition, the smaller the town or village inhabited, which would presumably increase the likelihood of direct intergroup contact, the more positive the assessment of relations (Gallová Kriglerová, 2006).

${ }^{8}$ Another report from the focus group discussions with young people aged 12 to 25 highlighted the fact that participants with moderate and tolerant views did not provide strong arguments in defence of their position and tended to avoid confrontation. On the other hand, intolerant views were largely based on insufficient, inaccurate or completely false information about minority groups (Farkašovská et al., 2011).

${ }^{9}$ Strikingly, the proportion of pupils who would not mind sitting next to a Roma pupil decreases the higher the level of education attained by their parents. $70 \%$ of those who refuse came from pupils living in bigger towns (50 to 100,000 inhabitants) and villages of up to 2,000 inhabitants. The highest proportion of positive responses came from the region with the highest proportion of Roma inhabitants (Prešov region) and the lowest from the region with one of the smallest Roma populations and almost no segregated settlements - Žilina region (Slovíková, 2012).
} 
on preventing intolerant or extremist views and behaviours in the classroom for which the inspectors lack the proper assessment tools (Správa, 2016a, 2016b).

Despite repeated findings of persistent negative attitudes and prejudice among Slovak pupils, there has been no qualitative or quantitative youth survey (Štefančík, 2012) designed to modify the existing curriculum, enrich methodological support or improve teachers' professional development. Moreover, it has also been established that there is a high prevalence of negative attitudes towards Roma among pre-service and in-service teachers and teaching assistants (Šramová \& Poliaková, 2010; Kusá, Kostlán, \& Rusnáková, 2010a; Rosinský, 2009; Kővérová, 2016).

An unrepresentative survey among primary school teachers showed that teachers displayed the largest social distance from Roma of all the groups researched. Teachers living in regions with a higher concentration of segregated Roma settlements displayed a higher prevalence of negative attitudes, and there was no correlation with age or years of teaching practice. However, the greater experience of teaching Roma pupils, the higher acceptance of Roma generally (Rosinský, 2009). Negative notions associated with Roma prevailed among prospective teachers and teaching assistants enrolled at pedagogical faculties. One difference which emerged between the two groups was represented by a higher rate of fear among future teachers which researchers attribute to a significantly smaller space dedicated to multicultural issues in their curriculum in comparison to the preparation of teaching assistants (Šramová \& Poliaková, 2010).

Qualitative research conducted among a small number of secondary school teachers revealed a whole array of negative stereotypes, often expressed in overtly racist terms with biological and genetic undertones (Kővérová, 2016). However, the survey pointed to an interesting difference between schools that had larger or smaller numbers of Roma students. While negative remarks about allegedly ingrained traits among the Roma were recorded mostly in schools with larger numbers of Roma, their teachers also expressed more empathy for their disadvantaged status and showed greater willingness to adjust their pedagogical approaches to what they conceived of as the Roma 'nature'. On the other hand, teachers from a more prestigious secondary school with a much lower proportion of Roma pupils tended to use more politically correct language and emphasised a 'colour-blind' approach, hence downplaying any of the differences among students from disadvantaged backgrounds.

Extensive research of interethnic relations in nine European countries (EDUMIGROM) ${ }^{10}$ pointed to widespread practices of 'othering' in schools which not only affect performance, attitudes to education and the future prospects of minority students but also their selfperception and identity formation (Szalai, 2010; Kusá, Kostlán, \& Rusnáková, 2010a). The accounts by Roma students from central European countries, including Slovakia, referred to a range of prejudiced and racist remarks made by teachers and peers which were often expressed as indirect hints or presented as innocent jokes. The interviews with Roma students showed that they often saw them as a regular occurence and therefore as normal.

\footnotetext{
${ }^{10}$ Ethnic Differences in Education and Diverging Prospects for Urban Youth in an Enlarged Europe was conducted in nine EU countries (the Czech Republic, Denmark, France, Germany, Hungary, Romania, Slovakia, Sweden, and the United Kingdom) and was coordinated by the Centre for Policy Studies of the Central European University in Budapest.
} 
One of the major differences between the western and eastern European countries was that teachers in the former seemed to be very conscious of their role in managing conflicts arising from interethnic encounters. Their counterparts in post-communist countries did not consider this to be their duty. When referring to racist or prejudiced incidents among students, most of them thought that the school had little to do with changing cultural habits, although they thought otherwise if the "perpetrators" were Roma. The role of teacher biases and discriminatory practices in schools was seen to partly explain ethnically differentiated assessments of performance (Szalai, 2011).

Despite a number of studies that point to the prevalence of negative attitudes among teachers, particularly towards the Roma, the role of teachers in reducing or reproducing prejudice has not been thoroughly studied in Slovak pedagogical research.

\section{Systemic constraints to reducing prejudice in schools}

Although the evidence points to an urgent need to deal with intergroup relations in Slovak classrooms, and school-based research among pupils and teachers has revealed a high prevalence of prejudice, particularly towards the Roma, these findings have not translated into practical pedagogical interventions and systemic support for teachers. The outcomes of the research are, at best, lists of recommendations for policy-makers, which barely impact on teaching practice.

There are, however, larger systemic obstacles ${ }^{11}$ which complicate any sustained effort at reducing prejudice in schools. Limitations are also posed by the curriculum, the way instruction is organized, the inappropriateness of quality control, the lack of evaluation of learning outcomes and teachers' lack of skills in dealing with sensitive topics.

The development of civic competencies and positive attitudes to diversity is not something the Slovak education system prioritizes, measures or supports. The curriculum provides only limited opportunities for developing values and attitudes and for designing and implementing interventions to reduce intolerance and prejudice. Although it is formally divided into broader thematic areas (e.g. People and Values, People and Society), competencies remain clustered within traditional academic subjects. The state educational programmes include additional cross-subject themes, including Multicultural Education (MCE) and Personal and Social Development; however, subject-specific knowledge remains the principal focus of education rather than the development of generic skills and attitudes and values. ${ }^{12}$

An unrepresentative survey among teachers showed that the majority of them consider MCE to be useful and emphasized the need to develop pupils' communication skills and

\footnotetext{
${ }^{11}$ Since providing a comprehensive description of the Slovak education system is beyond the scope of this paper, please refer to the Descriptions of national education systems - Slovakia (2016). Available at Eurydice portal: https://webgate.ec.europa.eu/fpfis/mwikis/eurydice/index.php/Slovakia:Overview.

${ }^{12}$ Although schools and teachers have relative autonomy in deciding the content and form of instruction while fulfilling the set competency standards, many rely on the use of the detailed syllabi from before the curricular reform of 2008. Although MCE is mandatory, there is no prescribed teaching method nor is there a full-fledged syllabus. The vast majority of schools state that it is integrated into other subjects, but there is no direct evidence of this except for references to it in the school educational programmes.
} 
promote respect for different sociocultural groups. However, almost $90 \%$ of teachers admitted they had problems planning MCE sessions, and more than $60 \%$ struggle to teach them as well (Petrasová, 2010). Other research ascertained that there was a lack of quality teaching materials and opportunities for teachers to advance their skills in MCE (Slovíková, 2011). The themes students indicated they would like to discuss during MCE sessions included world religions, human rights violations, cultural diversity and the Roma minority (Slovíková, 2012).

In the first four years of primary school, intergroup relations, stereotypes and prejudice are not covered in any way. Ethics is an elective subject taught from the first year of primary school but is available only to pupils who do not opt for religious education. ${ }^{13}$ Civic education (CE) is introduced only in year 6 and consists of one 45 -minute session per week. In secondary vocational schools the development of civic competencies is reduced to a minimum, while the CE taught at secondary grammar schools largely focuses on the acquisition of factual knowledge relating to the social sciences and humanities and consists of three 45 -minute sessions per week..$^{14}$

The data also reveal that the school subjects generally thought to provide the greatest potential for reducing prejudice suffer from teacher shortages and are taught by underqualified teachers. ${ }^{15}$ Although state institutions and a few NGOs attempt to compensate for the generally low quality of CE instruction most of the teaching resources are not accompanied by any proper training sessions, and only a few of them are developed after a thorough needs assessment of potential users or are co-developed by the teachers themselves. ${ }^{16}$ None of them is integrated into the existing curricula or educational programmes for teachers.

\footnotetext{
${ }^{13}$ The State Educational Programme in Ethics contains what could be regarded as positive, preventive measures, e.g. developing prosocial behaviour and empathy. It also contains a performance standard at the end of year 4 which requires pupils "to describe the differences in behaviour between boys and girls" (Etická výchova, 2015a, p. 9), while at the end of year 8 they are expected to "identify gender stereotypes in their environment and the media" (Občianska náuka, 2015a, p. 7). At higher levels, ethics deals very briefly with tolerance, does not include notions of diversity and focuses more on communication, empathy, and assertiveness (Etická výchova, 2015b).

${ }^{14}$ The so-called Framework Instruction Plans issued by the Ministry of Education specify the minimum number of classes for each mandatory subject. Schools can increase the number of sessions for particular subjects and make extensive use of this opportunity, but rarely for subjects like ethics and CE.

${ }^{15}$ According to the data from 2014, the proportion of civic education (CE) teachers without sufficient qualifications was $60 \%$ at the lower secondary level (years 5 to 9) and this had not changed since 2009. In both years almost half of all CE classes were taught by staff without the required qualification (43\% and $45 \%$ respectively). While secondary grammar schools benefited from having the lowest proportion of underqualified CE teachers (8\% in 2014 and 10\% in 2009), secondary vocational schools were affected more, with almost two fifths (39\%) of CE teaching staff being underqualified. The shortage of teachers qualified to teach CE at all levels of education was a little under 3,000 teachers in 2014 (Zistovanie kvalifikovanosti pedagogických zamestnancov a odbornosti vyučovania podla stavu k 31 . 01. 2014, 2014).

${ }^{16}$ Notable exceptions include toolkits developed by the civic association People in Peril and the Milan Šimečka Foundation. Some of these are designed for intergroup relations, stereotypes and prejudice. All were, however, project-based, lacked sustained funding and were not available nationwide. Most can be found on the Global Education portal at http://globalnevzdelavanie.sk/kniznica/novinky.
} 
Both input and output are deficient with limited curricular requirements and a lack of support for practitioners on the one hand, and a lack of assessment of pupil's skills and attitudes on the other. National standardised testing focuses solely on assessing basic literacies. Despite Slovakia is participating in almost all the international programmes that measure student competencies, ${ }^{17}$ in 2016 it will not participate in the only one to deal with civic competencies - the International Civic and Citizenship Survey (ICCS). The findings from the last ICCS in 2009 showed that Slovak 14-year old students scored above the average of participating countries but worse than 10 years before (Macháček \& Štava, 2012; Čapová \& Sklenárová, 2002)..$^{18}$

ICCS also surveyed the attitudes and practices of CE teachers. The three themes they felt the most confident to teach were civic rights and responsibilities, human rights and environmental protection. One of those they had the lowest confidence in teaching was 'various cultural and ethnic groups'. This also seems to have influenced what they considered to be the three most important objectives of CE. Only $15 \%$ of them thought 'the development of effective strategies to fight against racism and xenophobia' was of central importance.

Recently, the State School Inspectorate assessed quality in human rights education which included pupil tests. These did not point to a high deficit in knowledge but indicated that pupils were not particularly strong in applying the knowledge to real-life situations. The inspections revealed a deterioration in pupil performance but admitted that the tools used cannot clearly indicate the impact of human rights education on the incidence of intolerant or extremist views and behaviours (Správa, 2016a, 2016b).

\section{Enhancing teachers' prejudice-reducing competencies}

The teaching profession in Slovakia is professionalising, and this is evident in a shift away from conceiving of teachers as subject experts to facilitators of the learning processes. The draft quality standards are built around the 'interactional model of teacher as a reflective practitioner' (Kasáčová, 2005) and comprise competencies which are highly relevant to the subject of this article..$^{19}$ Their importance in reducing prejudice stems from the basis of the model, according to which teachers should not only be capable of delivering the content but also of actively constructing the syllabus and translating it into a meaningful set of activities

\footnotetext{
${ }^{17}$ Slovakia takes part in the international PISA, ICILS, TIMSS, PIRLS and TALIS assessments administered by the National Institute for Certified Educational Measurements. For more information, see www.nucem.sk.

${ }^{18}$ Previous research was conducted in 1999 as part of the Civic Education Study (CIVED) among students of the same age. Both studies revealed that students had solid knowledge but that their understanding was rather superficial and that they struggled with questions requiring a higher level of reading literacy and logical thinking.

${ }^{19}$ E.g. 'to understand the differences between pupils without prejudice and stereotypes', 'to understand differences between cultures in a multicultural environment and to identify their influence on the pupil's personality', and 'to perform action research' (Profesijné štandardy pre kategórie a podkategórie pedagogických zamestnancov, 2015).
} 
that takes account of pupils' learning needs. Teachers are also expected to assess the process and outcomes along the way through structured reflection. ${ }^{20}$

Most importantly, the teacher preparation should equip teachers with replicable competencies, including those needed to develop pupils' social skills. Hence, there is no need for undergraduate training to include 'yet another' specific component, in our case the theory and methodology of measuring attitudes. The model is congruent with continual reflective assessment during which teachers reflect on and alter their teaching without having to master sophisticated measuring tools and methods of analysis.

Yet, professional standards like these have not been adopted and both undergraduate training and continual teaching development await systemic change. Measuring attitudes is not a part of teachers' competencies profiles and there are only a limited number of researchoriented educational programmes. ${ }^{21}$

There is scope for designing and experimentally testing classroom-based prejudicereducing interventions, which could be used by teachers without them having to master sophisticated research designs. The inspirations could be derived from the three-year international Quality or Quantity? project (QoQ) ${ }^{22}$ that was designed to support in-service teachers by focusing more systematically on cultivating pupils' values and attitudes.

The QoQ project recruited teachers through an open call and a group was formed of 15 teachers from primary and secondary schools located in 12 different municipalities across Slovakia. They included teachers of Slovak language and literature, maths, physics, biology, geography, history, civic education and ethics, with varying lengths of teaching experience. Within a six-month period they attended an introductory training session, a mid-term sharing seminar and a final evaluation meeting.

At the introductory training session, the teachers were presented with a toolkit adopted from the English original ${ }^{23}$ containing activities for measuring pupil attitudes during regular lessons. Teachers were also provided with basic input on the cognitive, affective and behavioural dimensions of attitudes and were briefed on selected standard measuring methods.

After the training session, each teacher selected a simple activity from the toolkit according to their educational objectives, the school and student groups. The activities dealt

\footnotetext{
${ }^{20}$ Such an approach could help develop subject-specific methodologies, which several Slovak experts see as the way to enhancing the quality of undergraduate teacher training. See Kosová (2012).

${ }^{21}$ One of the few exceptions is action research, where teachers conduct investigations in the classroom in order to gain an insight into their own teaching and the outcomes, which often leads to change and innovation. Action research consists of a number of stages in which continuous self-reflection is a major part. For more information on action research methodology and practice, see Rychnavská \& Bačová (2015).

${ }^{22}$ The project was implemented through international collaboration involving NGOs - Reading International Solidarity Centre (UK), People in Need (Czech Republic) and the Milan Šimečka Foundation (Slovakia) - along with associated partners from Ireland and Ethiopia, the education faculties of 16 collaborating universities, including Oxford University, the University of Cambridge, Reading University, Charles University in Prague, Comenius University in Bratislava and the University of Matej Bel in Banská Bystrica.

${ }^{23}$ The activities used in the QoQ project are available here in Slovak: http://nadaciamilanasimecku. sk/akoviemezetofunguje.
} 
with various topics, including human rights, cultural diversity, global interconnectedness, sustainability and peace and conflict. Each was designed for the standard 45-minute class session and all contained a measuring element and an inconspicuous tool to collect evidence.

The methods utilised within the activities included brainstorming, various kinds of item sorting, ranking, scaling and voting. Depending on the activity pupils could work with visuals, worksheets and paper slips with pre-selected questions or answers. The teachers did not use standardized measurements or statistical tools since the aim of the project was not to train them as professional researchers but to test different techniques that can be used in everyday teaching.

Using the evidence collected from the activity the teachers analysed and interpreted their pupils' answers or choices and set the objectives of desired change for the forthcoming three-month period. Some of them moved away from the focus on attitudes and decided to develop pupils' skills instead. To achieve their objectives they prepared a set of interventions, respecting the curricular requirements and instructional standards of the school and subject. At the end of the cycle they either repeated the same activity or performed a modified activity to measure attitudes; some even chose a completely new one, to assess any change.

The experience from the whole cycle is reflected in the individual case studies ${ }^{24}$ that document the choices teachers made and the uncertainties and challenges they faced in the process.

\section{An example of a teacher's assessment of attitudes and attitudinal change $e^{25}$}

A primary school teacher from a small village in north-eastern Slovakia teaching at a school attended by both Roma and non-Roma pupils chose a simple activity with a set of six pictures portraying three girls and three boys of the same age with different skin colour. The task of altogether eighteen 13-year old pupils was to answer a simple question: 'What job will they do?'

The pupils were asked to assign each child an occupation from the list: scientist, nurse, cleaner, teacher, farmer, construction worker, physician and cook. One occupation could be assigned to more than one child. The children were not named but identified as a European, Asian or African boy or girl. The teacher decided to change one picture and replace it with a picture of a 'visibly'Roma child.

The results showed that the pupils assigned the occupations according to skin colour and gender. For instance, none of the boys in the class assigned the occupation of farmer or construction worker to a girl, and only one of the boys thought a girl could become a scientist. None of the boys was assigned to become a cook or nurse. None of the girls in the class imagined that any of the boys in the pictures could become a cleaner or nurse and only one thought that a girl could become a scientist. None of the pupils objected to doing the task.

\footnotetext{
${ }^{24}$ For more detailed case studies depicting the whole cycle of measuring attitudinal change see Drál, Galanská, \& Návojský (2014).

${ }^{25}$ This example was chosen to illustrate the approaches taken and the challenges faced by a teacher who focused explicitly on prejudice reduction.
} 
In addition to gender-based selections, there were clear patterns to assigning occupations on the basis of skin colour. All the pupils selected the European boy to become a scientist, teacher or physician. In their eyes the European girl would most likely become a teacher, physician or nurse. The majority of the boys and girls thought the African boy would become a farmer, while the African and Asian girls were mostly seen as cleaners or cooks, with a few pupils assigning the occupation of nurse to them. The Roma boy was given the occupation of construction worker or cleaner.

In the follow-up discussion the teacher asked an open question about the pupils' reasons for assigning particular occupations. The pupils were straightforward in their gender-based explanations: some occupations were simply for women and others for men. Jobs considered appropriate for women were those that were less physical and also less intellectually demanding or those connected to the household or taking care of other people, especially the elderly and children. The pupils emphasised that women have 'ingrained care-taking skills'. The male occupations were those considered to be physically, intellectually and technically more demanding and also those requiring more time. According to the pupils, males are better able to hold managerial positions and be active in politics.

Explanations connected to skin colour were less frequent but equally frank. Some pupils argued that children 'other than white children' do not have the right attitude to learning and therefore cannot get jobs requiring higher education.

Given the findings the teacher hesitated over whether to focus on the ethnic or the gender stereotypes. Since time was limited she wanted to concentrate on only one aspect and eventually decided to prepare sessions on gender. Besides being personally interested she thought that gender roles were closer to the everyday lives of the pupils than ethnic prejudice. During the follow-up sessions the pupils therefore explored fashion in different historical periods, watched a film about the status of women in different parts of the world, engaged in re-telling the story of Cinderella where the gender roles were swapped, selected gifts for a boy and a girl of different ages and so on.

For the final measure the teacher used a series of seven statements, all containing at least one gender role, three of which were related to occupations and two of which were the same as in the initial activity (a nurse and a scientist):

A girl can become a factory director.

Girls are weak and boys are strong.

A boy can work as a nurse.

When something bad happens, the boys did it.

The occupation of scientist is equally appropriate for girls and boys.

Girls are cleverer than boys.

Girls can be just as active in politics as boys.

Seventeen pupils partook in the activity and the results showed some shift in their thinking on the two occupations. While in the initial activity no male pupil had suggested the boy in the picture could pursue the occupation of nurse, this time three agreed with the statement 'A boy can work as a nurse' and three did not know. A similar shift was observed among the girls. Originally only one boy and one girl from the same class suggested that a (European) girl could pursue the occupation of scientist. In the end, four boys and five girls agreed with the statement that the occupation of scientist was appropriate for girls and boys. 
The teacher expressed satisfaction with the results and concluded that perceptions of gender roles in pupils' families are very traditional and she thought the fact that they admitted some occupations could be pursued by 'the other' gender as progress. The teacher did not reflect on the avoidance of race and ethnicity during the initial activity which is in line with general hesitance to focus on sensitive topics in Slovak classrooms.

\section{What can INTERMIN do to bridge the gap between research and classroom practice}

All the teachers in the QoQ project followed the same cycle described in the previous section: conducting the initial activity, designing and implementing interventions and measuring the impact. The processes and outcomes were diverse and reflected on at the final evaluation meeting. The experiences of testing activities and interventions in the three participating countries and dozens of schools ended with the creation of a new toolkit with activities and the reflections of the teachers on their application in practice (Allum et al., 2015).

Besides recording and reflecting the attitudinal changes of their pupils, the teachers stated that the conscious and sustained focus on attitudes proved to have positive side-effects on the class atmosphere, work dynamic and relationships between pupils and also with teachers and in several cases created a strong sense of belonging. The many different kinds of interactions revealed much that was unknown and which, intentionally or not, had transformed teaching practice as well as teacher attitudes to pupils and their work. Needless to say, the experience enhanced their skills in planning instructions, setting goals, choosing appropriate methods and developing learning materials. Finally, many of the teachers admitted that their attempt to cultivate the attitudes of others had made them realise the power they have and motivated them to reflect on their work with more modesty and caution.

During the measuring cycle teachers lacking a solid background in social psychology or statistics kept bringing up epistemological and methodological questions which professional researchers frequently have to deal with (see Popper \& Petrjánošová, 2016, this issue). It is worth listing some of them:

- Is there a norm or a desirable outcome we should strive to achieve in relation to attitudes? Who decides what they should be?

- What grounds of legitimacy do teachers have for shaping pupil attitudes, especially when they conflict with the attitudes of parents, peers or others?

- Should we inform the students about our intention to measure their attitudes? Is it cheating if we do not let them know?

- To what extent do our own expectations about pupils' attitudes affect the way we try to research them? And to what extent do the methods we use affect the results?

- To what extent do pupils say what they think we want them to say?

- How can we avoid falling into the trap of seeing what we want to see in our findings?

- What if there is no change in attitude after our interventions? What if we achieve the opposite? Is that failure?

- How durable is the attitudinal change we seem to have achieved?

- To what extent will the change in attitude affect pupil behaviour? (Drál, Galanská, \& Návojský, 2014, pp. 10-11) 
The lessons learned from the QoQ project may prove useful in designing and testing INTERMIN interventions since the aim is to provide tools for use in the classroom:

- A single teacher cannot make much of a difference; a coordinated, longer-term effort is needed to increase the chance of a durable attitudinal change occurring.

- Teachers who learn how to use a tool to 'measure' an attitude do not necessarily know what to do with the raw data and need guidance on formulating realistic goals for intervention.

- Once the objectives are defined teachers are capable of making the best of their pedagogical expertise to design interventions that are appropriate for their pupils and the curricular requirements as well as the adopted attitudinal objectives.

- Teachers are content in doing simple quantification operations and do not bother much with the issues of validity and reliability or with the congruence of initial and final measurements. They also need guidance on planning the data collection method and processing the collected evidence.

This snapshot of the issues raised and lessons learned during the QoQ project reveals that INTERMIN could help teachers effectively reduce prejudice in their classrooms but only if the measuring and intervention activities are simple to use, easily adjusted to the existing curricula and developed and tested alongside experienced teachers. In addition, the activities which truly bring about positive change should be designed and presented as teaching tools to achieve specific educational objectives and teachers need guidance on selecting adequate measurements and designing interventions.

\section{Conclusion: Will we be there "then"?}

The insufficient curricular requirements, significant shortages of qualified teachers, absence of performance control and outcome measurements along with the limited space for instruction and lack of methodological guidance do not constitute favourable conditions for quality civic education in Slovak schools. At the same time, academic research into attitudes and prejudice is generally not conducted with educational aims in mind and has no direct implications for teaching practice. While there is a clear gap between what we know and what we (do not) do to reduce prejudice in schools, the solution does not lie in inviting social researchers into every classroom or in training teachers to use sophisticated measures. The QoQ project did not produce any bullet-proof findings but at least it may inspire researchers to become more involved in developing tools teachers can easily incorporate into their regular lessons.

However, the identified gap between prejudice reduction research and practice is only one side of the challenge and this article has so far been based on implicit assumptions which are far from undisputable:

1. prejudice reduction is an effective way of bringing about positive social change and reducing inequalities;

2. schools can positively contribute to prejudice reduction;

3. by equipping teachers with skills and supplying schools with the tools to reduce prejudice the task will be accomplished. 
This last assumption was accounted for earlier, and it should be clear from the previous sections that effective prejudice reduction cannot occur unless the curriculum, quality control, undergraduate and continuous teacher training, and assessment of educational outcomes all undergo systemic change.

Even if all this is achieved the experience from the QoQ project suggests that there are clear limitations as to what we can achieve in the classroom. Attitudes do not change easily even under favourable conditions and are shaped by many more factors than simply those we want to control (see Popper \& Petrjánošová, 2016, this issue) through the provision of quality education. In the end, schools may only have a limited impact on the development of civic competencies and active engagement in pupils (Zápotočná \& Lukšík, 2010).

Finally, the prejudice reduction approach has its limitations, since by simply tackling the cognitive and emotional biases of dominant group members we may not only leave the underlying causes of social inequalities intact but even disempower the marginalized to effectively challenge them (Dixon, Durrheim, Stevenson, \& Cakal, forthcoming). Therefore, all well-intended interventions that seek to reduce intergroup bias should cautiously avoid colour-blind solutions and simply recognize differences instead of forcefully pushing for intergroup commonalities (Dovidio, Gaertner, Ufkes, Saguy, \& Pearson, 2016).

There are, clearly, problems affecting the academic research on prejudice reduction, both in its conceptual underpinning and the available options for correlational and experimental measurements (Lášticová \& Findor, 2016, this issue). But even the least contested and complicated measures and intervention tools remain inaccessible to schools.

While there are many conditions that have to be fulfilled before prejudice can be reduced in the classroom, the INTERMIN project has a chance of settling at least part of the debt by experimenting with measures, designing interventions and assessing impact, and all this can be done by effectively combining academic rigour and practical usefulness. If we are not ready to embrace an evidence-based and practice-oriented approach, it is likely we will see the development of sophisticated research designs, the use of wonderful teaching activities and the simultaneous rise of prejudice and extremism in our schools.

\section{References}

Allport, G. W. (1979). The nature of prejudice: 25th anniversary edition. New York, NY: Basic Books.

Allum, L., Drál, P., Galanská, N., Lowe, B., Návojský, A., Pelimanni, P., ... Zemanová, B. (Eds.). (2015). Ako vieme, že to funguje? Zistovanie postojov a postojových zmien počas vyučovania [How do we know it's working? Measuring attitudes and attitudinal change during lessons]. Bratislava: Nadácia Milana Šimečku.

Atlas rómskych komunít na Slovensku 2013. [Atlas of Roma Communities in Slovakia 2013]. (2014). Bratislava: UNDP.

Bieliková, M. et al. (2013). Prejavy intolerancie a násilia u žiakov základných a stredných škôl na Slovensku [Expressions of intolerance and violence among primary and secondary school pupils in Slovakia]. In R. Štefančík et al. Pravicový extrémizmus a mládež na Slovensku [Right-wing extremism and youth in Slovakia]. Brno: Tribun EU.

Čapová, M., \& Sklenárová, I. (2002). Výskum občianskeho vzdelávania štrnástročných žiakov v SR [Survey on civic education for fourteen-year old pupils in the Slovak Republic]. Bratislava: Štátny pedagogický ústav. 
Dixon, J., Durrheim, K., Stevenson, C. \& Cakal, H. (forthcoming). From prejudice reduction to collective action: Two psychological models of social change (and how to reconcile them). In F. Barlow \& C. Sibley (Eds.), Cambridge handbook of the psychology of prejudice. Cambridge: Cambridge University Press.

Dovidio, J. F., Gaertner, S. L., Ufkes, E. G., Saguy, T., \& Pearson, A. R. (2016). Included but invisible? Subtle bias, common identity, and the darker side of "we". Social Issues and Policy Review, 10(1), 6-46.

Drál, P., Kostlán, D., \& Kusá, Z. (2008). Country report on education: Slovakia. EDUMIGROM background papers. Budapest: Central European University.

Drál, P., Galanská, N., \& Návojský, A. (Eds.). (2014). Kvalita alebo kvantita? Zistovanie postojových zmien v globálnom vzdelávaní a multikultúrnej výchove [Quality or quantity? Measuring attitudinal change in global and multicultural education]. Bratislava: Nadácia Milana Šimečku.

Etická výchova - primárne vzdelávanie [Ethics - primary education]. (2015a). Bratislava: Štátny pedagogický ústav.

Etická výchova - nižšie stredné vzdelávanie [Ethics - lower secondary education]. (2015b). Bratislava: Štátny pedagogický ústav.

European Commission (2008). Discrimination in the European Union 2008. Results for Slovakia. Retrieved from: http://ec.europa.eu/public_opinion/archives/ebs/ebs_296_sheet_sk.pdf

European Commission (2015). Special Eurobarometer 437: Discrimination in the EU in 2015. Retrieved from: http://dx.doi.org/10.2838/325154

Farkašovská, E. et al. (2011). (Ne)tolerancia a diskriminácia - postoje a skúsenosti mládeže Spiša [(In)tolerance and discrimination - attitudes and experiences of young people in the Spiš region]. Košice: MVO Proxima.

Gallová Kriglerová, E. (2006). Prieskum názorov mladých ludí pre potreby kampane All Different - All Equal. [Opinion poll among young people for the All Different - All Equal campaign]. Bratislava: Iuventa.

Gallová Kriglerová, E., \& Kadlečíková, J. (2009). Kultúrna rozmanitost’ a jej vnímanie žiakmi základných škôl na Slovensku [Cultural diversity and how it is perceived by primary school pupils in Slovakia]. Bratislava: Open Society Foundation.

Huttová, J., McDonald, C., \& Harper, C. (2008). Making the mark? An overview of current challenges in the education for migrant, minority, and marginalised children in Europe. New York: Open Society Institute.

Hradiská, E., \& Ritomský, A. (2007). Spôsoby trávenia volného času v súvislosti so sebahodnotením mládeže a postojmi k extrémizmu [Ways of spending free time and young people's self-assessment and attitudes to extremism]. Bratislava: Národné osvetové centrum.

Juhaščíková, I., Škápik, P., \& Štukovská, Z. (2012). Základné údaje zo Sčítania obyvatelov, domov a bytov 2011. Obyvatelstvo podla národnosti [Basic data from the Census of inhabitants, houses and apartments 2011. Population by ethnicity]. Bratislava: Štatistický úrad SR.

Kasáčová, B. (2005). Reflexívna výučba a reflexia v učitelskej príprave [Reflective instruction and reflection in teacher training]. Banská Bystrica: Univerzita Mateja Bela.

Kosová, B. et al. (2012). Transformácia vysokoškolského vzdelávania učitelov v kontexte reformy regionálneho školstva. Záverečná správa a návrhy odporúčaní [Transformation of university teacher training in the context of education reform]. Banská Bystrica: Univerzita Mateja Bela.

Kotvanová, A., Müncnerová, L., \& Chaloupka, V. (2008). Vnímanie ludských práv a zásady rovnakého zaobchádzania u dospelej populácie SR [Perceptions of human rights and the principle of equal treatment among the adult population in the Slovak Republic]. Bratislava: Slovenské národné stredisko pre ludské práva.

Kövérová, E. (2016). Školy ako pozitívne deviantné systémy [Schools as positively deviant systems]. Pedagogika.sk, 7, 77-102. 
Kusá, Z., \& Zeman, M. (Eds.). (2008). Výskum európskych hodnôt 2008 [European values survey 2008]. Bratislava: Sociologický ústav SAV.

Kusá, Z., Drál, P., \& Kostlán, D. (2008). Country report on ethnic relations: Slovakia. EDUMIGROM Background papers. Budapest: Central European University.

Kusá, Z., Kostlán, D., \& Rusnáková, J. (2010a). Ethnic differences in education in Slovakia: Community study. EDUMIGROM community studies. Budapest: Central European University.

Kusá, Z., Kostlán, D., \& Rusnáková, J. (2010b). Ethnic differences in education in Slovakia: Survey report. EDUMIGROM survey studies. Budapest: Central European University.

Law, I., Nekorjak, M., Daniel, O., \& Vajda, R. (2009). Comparative report on ethnic relations. EDUMIGROM comparative papers. Budapest: Central European University.

Lášticová, B., \& Findor, A. (2016). Developing explicit measures of stereotypes and anti-Roma prejudice in Slovakia: Conceptual and methodological challenges. Human Affairs, 26(3), 233-252.

Macháček, L., \& Štava, E. (2012). Občianske vzdelávanie a výchova mládeže k občianstvu. Národná správa z medzinárodného výskumu občianskeho vzdelávania ICCS 2009 [Civic and youth citizenship education. National report on the international survey of civic education ICCS 2009]. Bratislava: Národný ústav certifikovaných meraní vzdelávania.

Občianska náuka - nižšie stredné vzdelávanie. [Civic education - lower secondary education]. (2015a). Bratislava: Štátny pedagogický ústav.

Občianska náuka - gymnázium so štvorročným a pätročným vzdelávacím programom. [Civic education - secondary grammar schools offering four- and five-year educational programmes]. (2015b). Bratislava: Śtátny pedagogický ústav.

Descriptions of national education systems - Slovakia. (2016). Available at Eurydice portal: https:// webgate.ec.europa.eu/fpfis/mwikis/eurydice/index.php/Slovakia:Overview.

Petrasová, A. (2010). Výsledky dotazníkového prieskumu: Realizácia multikultúrnej výchovy $v$ základných a stredných školách [Questionnaire-based research findings: Introducing multicultural education into primary and secondary schools]. Bratislava: Inštitút pre dobre spravovanú spoločnosté

Popper, M., \& Petrjánošová, M. (2016). Do we know what we are asking? Individual and group cognitive interviews. Human Affairs, 26(3), 253-270.

Profesijné štandardy pre kategórie a podkategórie pedagogických zamestnancov. [Professional standards for categories and subcategories of teaching staff]. (2015). Bratislava: Metodickopedagogické centrum.

Report on the situation and rights of persons belonging to national minorities 2014. (2015). Bratislava: Office of the Plenipotentiary of the Government of the Slovak Republic for National Minorities.

Rosinský, R. (2009). Etnické postoje učitelov, študentov a žiakov I. stupña ZŠ (s akcentom na rómsku etnickú skupinu) [Ethnic attitudes of teachers, students and pupils at the first level of primary school (focusing on the Roma ethnic group)]. Nitra: Univerzita Konštantína Filozofa.

Rychnavská, M., \& Bačová, V. (2015). Akčný výskum - cesta skvalitňovania pedagogickej praxe [Action research - improving teaching practice]. Bratislava: Metodicko-pedagogické centrum.

Slovíková, M. (2011). Multikultúrna výchova v základných a stredných školách. Výskum názorov a skúseností žiakov [Multicultural education at primary and secondary schools. Research on pupils' opinions and experiences]. Bratislava: Ústav informácií a prognóz školstva.

Slovíková, M. (2012). Vzor tolerantného správania mladých ludí v rodine a v škole [A model of tolerant behaviour for young people in the family and school]. Bratislava: Ústav informácií a prognóz školstva.

Správa o stave a úrovni výchovy a vzdelávania k ludským právam v základnej škole v školskom roku $2015 / 2016$ v SR [Report on the state and quality of human rights education in primary schools in the 2015/2016 school year]. (2016a). Bratislava: Státna školská inšpekcia. 
Správa o stave a úrovni výchovy a vzdelávania $\mathrm{k}$ ludským právam $\mathrm{v}$ strednej škole $\mathrm{v}$ školskom roku $2015 / 2016$ v SR [Report on the state and quality of human rights education in secondary schools in the 2015/2016 school year]. (2016b). Bratislava: Štátna školská inšpekcia.

Szalai, J. (Ed.) (2010). Being 'visibly different': Experiences of second-generation migrant and Roma youths at school. A comparative study of communities in nine member states of the EU. Budapest: Central European University.

Szalai, J. (2011). Ethnic differences in education and diverging prospects for urban youth in an enlarged Europe. EDUMIGROM summary findings. Budapest: Central European University.

Šramová, B., \& Poliaková, E. (2010). Multikultúrna edukácia v školách [Multicultural education in schools]. In B. Šramová et al., Tolerancia a intolerancia v spoločnosti [Tolerance and intolerance in society] (pp. 55-64). Bratislava: Melius.

Štefančík, R. (Ed.) (2012). Slovenská mládež v zrkadle sociologických výskumov po roku 1993 [Slovak young people reflected in sociological research after 1993]. Bratislava: Slovenská sociologická spoločnosî pri SAV.

Vašečka, M. (2001). Vztah majoritnej populácie k Rómom [Relations between the majority population and the Roma.] In O. Gyarfášová, V. Krivý, \& M. Velšic, Krajina v pohybe [Country in motion]. Bratislava: Inštitút pre verejné otázky.

Vašečka, M. (2002). Vztah majority k Rómom [Relations between the majority and the Roma]. In M. Vašečka (Ed.), Čačipen pal o Roma. Súhrnná správa o Rómoch na Slovensku (pp. 335-351). Bratislava: Inštitút pre verejné otázky.

Zápotočná, O., \& Lukšík, I. (2010). Podiel školy na formovaní aktívneho občianstva [The impact of schools on shaping active citizenship]. Sociológia, 42, 492-515.

Zistovanie kvalifikovanosti pedagogických zamestnancov a odbornosti vyučovania podla stavu $k 31$. 01. 2014. [Survey on teaching staff qualifications and teaching expertise on $31^{\text {st }}$ January 2014.] Bratislava: Centrum vedecko-technických informácií SR. Available online at: https://www.minedu. sk/kvalifikovanost-pedagogickych-zamestnancov/.

Institute of European Studies and International Relations,

Faculty of Social and Economic Sciences,

Comenius University in Bratislava

Mlynské luhy 4

82105 Bratislava

Slovakia

E-mail: peter.dral@fses.uniba.sk

E-mail: andrej.findor@fses.uniba.sk 